University of Windsor

Scholarship at UWindsor

2013

\title{
Access to Justice: Is Legal Services Regulation Blocking the Path?
}

Noel Semple

University of Windsor, Faculty of Law

Follow this and additional works at: https://scholar.uwindsor.ca/lawpub

Part of the Law Commons

\section{Recommended Citation}

Semple, Noel. (2013). Access to Justice: Is Legal Services Regulation Blocking the Path?. International Journal of the Legal Profession, 20 (3).

https://scholar.uwindsor.ca/lawpub/3

This Article is brought to you for free and open access by the Faculty of Law at Scholarship at UWindsor. It has been accepted for inclusion in Law Publications by an authorized administrator of Scholarship at UWindsor. For more information, please contact scholarship@uwindsor.ca. 


\section{Access to Justice: Is Legal Services Regulation Blocking the Path?}

By Noel Semple ${ }^{1}$

SSHRC Postdoctoral Fellow. Centre for the Legal Profession, University of Toronto Faculty of Law.

\section{North America's Access to Justice Problem}

Access to justice requires, among other things, that expert legal services be reasonably available to individuals of modest means who have legal needs. In the United States and in Canada, the inaccessibility of legal services has been widely recognized (Legal Services Corporation, 2009; CBA A2J Committee, 2013). The swelling tide of unrepresented litigants in courts and tribunals is one clear manifestation of this problem (Rigertas, 2012;

Choudhry et al., 2012). However there are also widespread ummet needs for non-disputerelated legal services such as advice about mortgage transactions (Hadfield, 2010). Not everyone who has a legal need wants or would benefit from expert legal services (Kritzer, 2010). However in many cases going without them has seriously negative effects, which often extend beyond the individual experiencing the need (Albiston and Sandefur, 2013, p. 111). Public funding for legal aid is stagnant or shrinking in most parts of North America (Buckley, 2010; Barnett, 2012). This adds urgency to the question of how private sector legal services might be made more accessible.

Why would a person with a legal need go without expert legal services? The financial reasons might include her estimate of the total eventual cost of the service, as well as "cost structure" factors such as the requirement to produce a cash retainer and the unpredictability of the final bill. Simple transactional legal services seem to be relatively

1 mail@noelsemple.ca The author is grateful for the helpful comments provided on drafts of this article by Michael Trebilcock, Malcolm Mercer, and the peer reviewers of this journal. 
affordable in North America (Sandefur 2012), but hiring a lawyer for litigation can quickly become cost-prohibitive for any middle-or low-income individual (Todd, 2012; MacFarlane, 2013).

However "money isn't everything" in individuals' decisions about whether or not to pay for help (Sandefur, 2012). Research shows that the most important variable determining whether or not a person gets expert help for a legal problem is not the person's income, but rather the nature of the problem (Pleasence and Balmer, 2010; Baxter et al., 2012). This is partly a result of inconsistent legal consciousness (Sandefur, 2012). Many people do not perceive the legal dimensions of their life problems and experiences, or the value of legal services in responding to them (Susskind, 2008). Some people who can afford to hire lawyers do not do so; others who might borrow or deplete savings in order to afford medical or other services will not do so for legal services (Myrick et al., 2012). Negative perceptions of either the value of the service, or of the experience of dealing with the service provider may deter people. There are some who would be willing and able to pay for legal services, but do not find the variety of consumer legal services currently available in North America to be appealing.

Justice is less accessible in the United States and Canada than it is in other parts of the developed common law world, at least according to some measures (Hadfield, 2010; Agrast et al., 2011). This article suggests one reason why this might be the case: North American legal services regulation is exacerbating the access to justice problem. Previous scholarship has identified accessibility ramifications of various aspects of American regulation (Luban, 1988; Rhode, 1996; Abel, 2011; Hadfield, 2012). This article focuses on two distinctive features which unite American and Canadian regulatory regimes and 
distinguish them from those of other developed common law countries. First, North American regulators seek to preserve the unity of the legal profession through universal licensure, while other common law jurisdictions now license multiple legal occupations such as solicitors, barristers, and conveyancers. Second, North American regulators seek to insulate lawyers by forbidding non-lawyer firm ownership and management. This policy has gradually been abandoned in recent decades by regulators in England \& Wales and Australia (and, to a more modest extent, their smaller common law neighbours). The article concludes that, while regulatory reform would not be a silver bullet for access, North American legal services regulators should understand and work to mitigate the effects of their policies on accessibility.

\section{Universal Licensure and Access to Justice}

Occupational licensing forbids anyone who has not been granted a license from doing certain work. Economists argue that licensing reduces competition and increases price by restricting the supply of services (Friedman and Kuznets, 1954; Pagliero, 2010). Legal services licensing regimes are also often inaccurate predictors of service quality (Kritzer, 1998; Moorhead, Sherr and Paterson 2003). Critics have therefore called for legal services licensing barriers to be either abolished (Winston et al., 2011), lowered (Barton, 2001), or reserved for a smaller portion of the legal services marketplace (Abel, 2009). Nevertheless, there is a consensus among policy-makers that licensing is a necessary prophylactic to prevent incompetent and fraudulent practice, the dire consequences of which cannot be fully corrected after the fact by other interventions (Barton, 2011). 


\subsection{The Economic Critique of Universal Licensure}

However, North America is distinguished from other common law regions by the universalist nature of its licensing regimes. With a few small exceptions, ${ }^{1}$ in these jurisdictions the only licensed category of provider is "lawyer," all lawyers must surmount the same licensing barriers, and all lawyers are licensed to provide the same services (Wilkins, 1993; Peppet, 2005).

The UK and Australia, by contrast, have less onerous forms of licensing in the legal services sector. In England \& Wales, the mere offering of legal advice, without preparing documents or appearing in court, does not require a license (Legal Services Act 2007, s. 12). This opens the door to accessible service models which are impossible in North America, such as Citizens' Advice Bureaux (Trebilcock, 2008).

Although most legal services in the UK and Australia are provided by licensed professionals, these countries issue different types of legal license granting practitioners different scopes of practice. This multiple licensing approach has been identified as a way to mitigate the anti-competitive effects of licensing in the legal services sector (Parker, 1999; Brockman, 2010; Albiston and Sandefur, 2013), without abandoning licensing's prophylactic quality guarantee. Multiple licensing is meant to foster competitive regulation, wherein self-regulatory legal occupations compete with each other. In addition to competing for clients (Shaked and Sutton, 1981), they are also supposed to compete to attract practitioners to their ranks, and compete to convince the state to expand their spheres of jurisdiction (OECD, 2007; Stephen, 2013). Regulatory competition can foster access to justice by rationalizing barriers to entry and disciplining their unwarranted elevation by rent-seeking self-regulators. 
Suppose, for example, that the established practitioners who control England's selfregulatory Council for Licensed Conveyancers are tempted to increase the difficulty of their entrance exam in order to reduce competition from new entrants. Competitive regulation can discipline this rent-seeking in two ways. First, applicants deterred by the higher barrier to entry may choose to become solicitors instead, and thereby compete with conveyancers. Second, as the quantity of conveyancers is constrained and prices increase, their jurisdiction becomes increasingly tempting to other occupational groups. These other groups may be incentivized to apply to the Legal Services Board to expand into conveyancing services in order to reap the high profits. Conversely, if the conveyancers roll back their entry barriers to the extent that their licensees are incompetent to provide the service promised, then their reputation will suffer and consumers will turn to the alternatives. As the argument runs, the combination of multiple licensing and regulatory competition will rationalize entry barriers in accordance with the public interest, impeding access to justice no more than is strictly necessary to protect quality (OECD, 2007; Stephen, 2013, Ch. 7.). It will mitigate the price-inflating effects of occupational licensure, and foreclose the possibility of self-regulatory rent-seeking.

\subsection{Evaluation of the Universal Licensing Critique}

The economic critique of universalist licensure offers a convincing account of how legal services regulation may be impeding access to justice in the United States and Canada. However, it must be acknowledged that occupational groups do not invariably compete aggressively to seize jurisdiction from each other. One group may be co-opted by another (Coy and Hedeen, 2005), or they may reach accommodations to avoid cut-throat competition (OECD, 2007). There is some evidence that this is what happened in England 
after the creation of the conveyancer profession in 1987 (Kerridge and Davis, 1999; Webb, 2008), and after the extension of advocacy rights to solicitors in the 1990s (Kerridge and Davis, 1999; Boon and Flood, 1999).

One possible access to justice drawback of multiple licensing is its complexity and attendant compliance costs for practitioners. Law firms (and therefore their clients) must pay the cost of running the front-line regulators, the meso-regulator, and adjunct bodies such as the Legal Services Consumer Panel in England \& Wales ((Legal Services Board (England \& Wales), 2012, p. 10). Multiple licensing is a major reason why there are 55 different legal services regulators in Australia (Mortensen, 2013, p. 221). Universal licensing is comparatively straightforward, and this element of the cost of doing business is presumably lower for North American firms.

\section{Insulation of Law Firms and Access to Justice}

Insulation of lawyers from non-lawyer influence is another distinctive and potentially access-impeding feature of North American legal services regulation. Only licensed lawyers may own or manage law firms, and lawyers are generally forbidden to enter fee-sharing or other arrangements which would subject their professional judgment to the influence of non-lawyers (Paton, 2010; Hadfield, 2012; Moliterno, 2013). North American insulating rules include those prohibiting and tightly controlling multidisciplinary practice (MDP) and alternative business structures (e.g. ABA Model Rules of Professional Conduct, R. 5.4(d)(1); Law Society Act (Ontario) , s. 61.0.1(4)).

In the UK and Australia, by contrast, legal services regulators have mostly abandoned insulating rules. Could American and Canadian regulators improve the 
accessibility of justice by following the same path (Knake, 2012; Hadfield, 2012)? There are three ways in which insulating rules plausibly impede the accessibility of justice: (i) by increasing the price of capital, (ii) by impeding the emergence of large consumer law firms, and (iii) by precluding potentially access-enhancing inter-professional collaborations.

\subsection{Insulating Regulation Increases the Cost of Capital}

Although not as capital-intensive as some ventures, law firms do require capital, for example to purchase technology and fund accounts receivable (Bishop, 1989; Dzienkowski and Peroni, 2000). Most businesses can choose between a variety of capital sources, and can be expected to choose the mixture which meets their needs at the lowest possible cost (Miller, 1996). However North American law firms are restricted by insulating regulation to two sources of capital: bank loans and licensed lawyers. This restriction on supply presumably increases the price which they must pay for capital. Banks, for example, might not offer their lowest interest rates to law firms, because they are not required to compete with venture capitalists and investment bankers to capture this business.

Like other costs of doing business, the increased cost of capital is presumably passed on to consumers, thereby raising prices and exacerbating the financial impediments to accessibility. An oft-cited rule of thumb is that, in exchange for investing in an American law firm, partners can expect to retain as profit at least $33 \%$ on every hour billed by the associates (Samuelson and Jaffe, 1990; Goldberg, 2009). Non-lawyer investors might be willing to undercut this healthy margin if allowed by regulation (Gillers, 1985).

One reason why partners demand high returns for capital left in the firm is that they are usually highly exposed to the risk of the firm failing of faltering. The safe course for a law firm partner is to diversify - maximize draws on firm profits and invest them 
elsewhere, so as to avoid excessive exposure to the fate of the firm. Thus, firms which retain earnings to fund expansion or innovation risk losing their partners (Hadfield, 2008; Campbell, 2012).

Public equity financing - which Australia permits for law firms- facilitates capital placement with very low transaction costs (Miller, 1996, p. 98;). It also makes it easy for investors to diversify, which encourages them to accept risk at a lower cost (Hadfield, 2008; Iacobucci \& Trebilcock 2014). In principle, equity market financing could facilitate the emergence of more innovative and accessible consumer law firms. For example, suppose an entrepreneurial American lawyer wishes to start an unconventional law firm which will use technology, consumer branding, and legal process outsourcing to offer fixedfee litigation services to middle-income individuals. This lawyer is looking for venture capital, but balks at the high interest rate quoted by the bank. She can form a partnership with another lawyer who has money to invest, but this would be a risky proposition for that second lawyer. Becoming a partner in a law firm requires a very substantial commitment of financial and human capital. The investment being proposed is far from a sure bet.

By contrast, an initial public offering on a stock exchange would allow millions of investors to share in the potentially high rewards of this innovative venture, while bearing only a small risk. Thus, the restrictions on capital supply not only increase the cost of doing business, but may also render the very types of capital-intensive innovation which would increase the accessibility of justice difficult if not impossible. As Gillian Hadfield puts the point, "innovation in legal markets is ... severely hampered by limitations on the capacity for innovators... to finance their entrepreneurial efforts" (Hadfield, 2008, p. 139). 


\subsection{Insulating Regulation Keeps Firms Small}

North America's insulation of lawyers from non-lawyers also seems to be suppressing the emergence of larger firms, which in turn impedes access to justice. Private-sector legal services for North American individuals (as opposed to corporations and institutions) are predominantly provided by lawyers working alone or in small firms (Heinz et al., 2005). In the UK and Australia, by contrast, there are now examples of large, consumer-focused law firms. The new English firm Co-Operative Legal Services, which provides services exclusively to individuals, plans to grow to 3000 lawyers by 2017 (Robins, 2012). Australia's Slater \& Gordon, a publicly-traded corporation providing individual-client legal services, employs 1350 staff in 69 locations (Slater \& Gordon, 2012). Both of these firms are much larger than the largest North American consumer law firms, which have less than 100 lawyers. ${ }^{2}$ Both Co-Operative Legal and Slater \& Gordon serve individual clients almost exclusively. Both firms serve the civil legal needs most commonly experienced, such as conveyancing, family law, estate law, and plaintiff-side personal injury matters. It is no coincidence that both of these firms have non-lawyer ownership, which is illegal in North America. Insulating regulation impedes the emergence of large, capitalintensive consumer law firms, by restricting their access to capital (OECD, 2007).

\subsubsection{Economies of Scope}

Why might bigger firms offer more accessible legal services? The access-enhancing opportunities offered by large firms can be divided into three categories: economies of scope, risk-spreading, and economies of scale. Economies of scope exist when a single firm can produce a set of different outputs more efficiently than multiple firms can (Teece, 1980). A large law firm might achieve economies of scope by providing services in multiple consumer legal areas, e.g. family law, estate law, and real estate. An individual is likely to 
have legal needs in several of these areas over time, and (s)he can be more efficiently and cost-effectively served by a firm which has a file on the client with information from past retainers.

A sole practitioner or small firm can capture economies of scope by being a generalist, working in multiple practice areas. However generalism in a solo practice or small firm comes at price-the firm loses the specialization benefits achieved by working consistently in a given field (Moorhead, 2010; Stephen, 2013, Ch. 8). The larger a firm is, the more readily it can simultaneously capture both economies of scope and the benefits of specialization, by including specialists in multiple areas (Stephen and Melville, 2008). The attendant economies of scope should permit lower prices for repeat clients, and the specialization should foster better quality service.

\subsubsection{Risk Spreading and Flat Rate Services}

Larger firms also have greater potential to spread risk, which in turn allows lower prices and more accessible services (OECD, 2007). Having multiple practice areas mitigates the effects of business cycles on each of them (Gilson and Mnookin, 1985; Stephen, 2013). For example, if a firm's personal insolvency practice suffers during an economic boom, then real estate transactions may compensate. A firm enjoying this form of stability can achieve consistent profitability at lower price points.

Risk-spreading is also the reason why larger firms are better positioned to offer fixed fee (flat-rate) legal services for contested matters, which have significant access to justice benefits. Since the mid- $20^{\text {th }}$ century, hourly billing has become the dominant business model for North American lawyers handling contested matters, with the exception 
of certain tort claims where contingency fees predominate (Brockman, 2004; Woolley, 2004; Fortney, 2005).

The access to justice problem with hourly billing is the financial uncertainty and risk which it requires clients to bear. While it is certainly difficult for a person of modest means to commit to paying $\$ 10,000$ for representation in a contested divorce, it is much more difficult to make that commitment if that person is told at the outset that the legal service could cost as much as $\$ 20,000$. Fixed fees make legal services more accessible because they clearly limit the client's financial exposure to the firm. Even if the average cost of a legal service is the same under the fixed fee model as it would be under hourly billing, removing the risk makes the service easier to afford. According to a recent UK survey, $87 \%$ of those who paid for legal services via fixed fee were satisfied with the service, compared to $73 \%$ of those who paid an hourly rate (Legal Services Consumer Panel (UK), 2013).

Why, then, don't North America's consumer law firms offer fixed fee services in contested matters? In small firms, the dominance of hourly billing reflects the difficulty of predicting how much work a retainer in a contested matter will require. Ray Worthy Campbell identifies the "runaway engagement" risk, which can lurk in even apparently straightforward cases, as an impediment to flat rate billing (2012, p. 59). Indeed, the cases which make it to the top-level appellate courts after thousands of hours of lawyer labour often have nothing initially apparent in their facts to distinguish them from numerous other cases which settle quickly. Even setting aside the extreme runaway engagements, there may be significant variance in the quantity of time necessary to resolve the garden variety cases which come into a personal injury or family law firm. A solo practitioner who 
handles 200 divorce files may not have enough data to reliably predict how much time cases will require. She thus perceives no choice but to bill by the hour.

Larger firms can more readily quantify and accept the risk of unpredictable labour requirements in contested cases, and they are therefore better positioned to offer flat rate services. A large firm which handles 10,000 divorce files in a year can learn to predict the labour inputs necessary to resolve cases, and identify the attributes which make a case more or less labour-intensive to resolve. Using this data, the firm should be able to quote fixed fees which allow it to remain consistently profitable.

As predicted by this analysis, flat rate consumer legal services for contested matters are now being offered by large, well-capitalized firms in the UK and Australia. The Legal Services Consumer Panel recently reported that $42 \%$ of consumer legal services delivered in England \& Wales are now paid for with fixed fees (Legal Services Consumer Panel (UK), 2013). Co-operative Legal Services offers telephone consultation about family law matters for $£ 175$, and will review court documents for $£ 50$ (Rose, 2013; Bindman, 2013). Australia's Slater \& Gordon also offers fixed fees in family law, which the lawyers quote to the clients at the outset after an evaluation of the case (Slater \& Gordon, 2013).

\subsubsection{Economies of Scale}

Economies of scale are the third reason why bigger firms might be more accessible (Knake, 2012). Economies of scale are reductions in the average costs of producing outputs which occur as the scale of production increases (Pratten, 2005). For example, the cost of bringing specialized expertise to bear on each file decreases as a firm grows. As noted above, a large firm practicing in multiple areas can have specialists in each, so that each lawyer spends less of his or her time maintaining legal expertise in multiple areas and 
more time serving clients. If the firm's work practices are sufficiently collaborative, then knowledge can also be efficiently shared within its walls (Hadfield, 2000) which further reduces the cost of applying expertise to a file.

Scale can also reduce labour costs by allowing workers to be deployed more efficiently (Heinz et al., 2005). A sole practitioner might need an administrative assistant to work four days per week. However, because it is difficult to hire someone on these terms, (s)he may be obliged to make do with a full-time assistant or a $1 / 2$ time assistant (Gilson and Mnookin, 1985). With a full-time assistant the lawyer will waste labour costs; with a $1 \frac{1}{2}$ time assistant the lawyer must perform some administrative tasks herself (which is a waste of her skills). In either case, the mismatch will increase the lawyer's overhead and therefore the cost of services.

Large firms might also be better positioned to economize on relatively expensive lawyer labour by substituting less-expensive non-lawyer labour. For example, Frank Stephen (2013) suggests that they might assign non-lawyers to gather information from clients and direct legal inquiries to specialists in a head office. Stephen cites data from Australia showing that incorporated legal practices (ILPs) have significantly more paralegal employees per lawyer employee than do traditional partnership firms and sole proprietorships. They also have higher operating profit margins - 33.8\% in ILPs and 26.2\% in unincorporated firms (Stephen, 2013, p. 136). If this form of business organization produces higher profit margins due to greater efficiency, then competition should eventually pass those benefits on to consumers through lower prices. 
To the extent that a legal service is simply a certain amount of a lawyer's time, economies of scale will be relatively modest (Hadfield, 2008). However technological progress is creating opportunities for consumer law firms to make investments which enhance access and profit, if the firms are large enough to recoup these fixed costs. Gillian Hadfield's work suggests that the predominance of expert lawyer labour in producing legal products and services is an artefact of $20^{\text {th }}$ century technology and regulation. She predicts a new, more accessible market, in which "human capital is transformed into concrete forms such as documents, processes, organizations, and procedures" (Hadfield, 2008, p. 137). In such a market, Hadfield argues, regulatory impediments to firm growth are a major roadblock to access-enhancing innovations.

Access-enhancing information technology can be subject to significant economies of scale. An interactive legal services website is expensive, but a firm would only have to build it once (Iacobucci \& Trebilcock, 2014). Also subject to economies of scale are branding and marketing efforts, which can reduce clients' "search costs" - the work involved in identifying a legal service provider which can meet one's needs (Hadfield, 2012; Stephen 2013). Marketing also has the potential to enhance legal consciousness, which was identified above as a significant contributor to the access to justice problem. Large consumer firms might be able to deploy niche marketing campaigns to reach marginalized groups who have their legal rights violated on a regular basis, such as isolated senior citizens, agricultural labourers, and sex trade workers.

Another investment which is subject to significant economies of scale is research and development of accessible consumer legal services and products. Justice becomes more accessible when consumer law firms bring to market innovative legal products and 
services. To succeed, such initiatives must be informed by comprehensive market research about what average people actually want and are prepared to pay for (Hadfield, 2012). As firm size increases, such efforts become more feasible and economical.

\subsection{Insulating Regulation Prevents Collaboration with Non-Lawyers}

In addition to increasing the cost of capital and suppressing firm size, regulation arguably impedes the accessibility of justice by foreclosing some forms of collaboration between lawyers and non-lawyers. It is not only non-lawyer capital from which North American law firms are insulated, but also non-lawyer leadership and collaboration. Multidisciplinary practices, in which lawyers and non-lawyers collaborate as equals, are regulated so tightly in the United States and Canada that they are almost non-existent (Love, 2002 at R. 5.4(b); Paton, 2010; Rappaport, 2008). Nor are lawyers permitted to subject their professional judgment to any non-lawyer other than a client (Love, 2002, R. 5.4(a) and R. 5.4(d)(3); Law Society of British Columbia, 2009 at 3.6.7; Law Society of Upper Canada, 2000 at R. 2.08(8)). Even without becoming larger than they currently are, firms permitted to collaborate more intensively with non-lawyers might innovate to enhance access (Susskind, 2008).

\subsubsection{Economies of Scope, Risk-Spreading, and Consumer Brands}

"One-stop shopping" economies of scope are available from multi-disciplinary practice. For example, an individual who is buying a home will often require the services of both a real estate agent and a lawyer. In North America's current regulatory environment, (s)he must search for, evaluate, retain, and instruct two independent firms to meet these needs (OECD, 2007, p. 49). Absent insulating regulation, integrated professional service 
firms can emerge offering package deals including both legal and other services (Director General of Fair Trading (UK), 2001; Dzienkowski and Peroni, 2000).

Non-legal retail and service companies have expertise which can help lawyers provide access to justice. Supermarket executives may not know anything about estates or divorces, but they are likely to have robust procedures and institutional knowledge for human resources and marketing (Stephen, 2013). Large retail firms also usually have strong consumer brands, and are in a position to make long-term investments without immediate profit (Knake, 2012). A law firm looking to provide innovative access to justice solutions may need all of these things, and collaboration with the supermarket would offer ready access to them (Stephen, 2013, Ch. 8; Clementi, 2004). Frank Stephen suggests that such collaborations may also improve legal service quality, insofar as the consumer brand will be motivated to ensure that no services which would degrade its brand capital are provided under its name (Stephen, 2013, Ch. 8). In the United Kingdom, regulatory liberalization under the Legal Services Act 2007 has already produced initiatives along these lines, including Stobart Barrister and Bott Aviation. Whether or not such collaborations produce more favourable rulings or settlement terms for clients, they may well improve the client's experience of interacting with the firm. Communication and "customer service" are common sources of client dissatisfaction with lawyers (e.g. MacFarlane, 2013), and collaboration with non-lawyers might help firms do better.

\subsubsection{Technology-Enabled Accessible Services}

Non-lawyer collaboration can also help lawyers produce more accessible and affordable legal products. Richard Susskind has argued that many legal services which are currently delivered through labour-intensive "bespoke" lawyer efforts can be 
commoditized (Susskind, 2008, p. 29). Examples include form contracts and automated online dispute-resolution services (Lodder and Zeleznikow, 2005). Because they leverage legal expertise to serve many clients instead of only one at a time, these products or commodities are much cheaper than actually retaining a lawyer (Kobayashi and Ribstein, 2011). Even if inferior to personalized assistance, such commodities might bring expert legal help to people who would not be able to afford a lawyer (Stephen, 2013, Ch. 8).

Taking advantage of such opportunities typically requires substantial non-legal expertise, often in information technology fields (Campbell, 2012; Kobayashi and Ribstein, 2011). One example is quantitative legal prediction (QLP) (Hadfield, 2008). QLP uses large databases of previously-resolved cases to inductively predict likely outcomes from a given fact scenario (Katz, 2013). Corporate clients are already benefitting from QLP (see e.g. McShane et al., 2012), but it could also enhance access to justice for individuals.

\subsubsection{Is Regulation Impeding Collaboration?}

Lawyer collaboration with non-lawyers has significant potential to foster the accessibility of justice today, but whether insulating regulation is actually preventing such collaboration may be contested. The regulatory status quo allows North American lawyers to collaborate with others by purchasing their services and products, or by employing and supervising them (Dzienkowski and Peroni, 2000). However, North America's insulating regulation sharply limits the types of collaboration which are currently possible (Kobayashi and Ribstein, 2011, p. 1188). North American law firms may source nonlawyer labour internally by employing and supervising non-lawyers, but they cannot have non-lawyers supervise lawyers. If non-lawyers cannot collaborate with lawyers in their manner of choice, they may not collaborate at all or they may be forced to adopt less 
efficient and more costly "second-best" alternatives for collaboration (Dzienkowski and Peroni, 2000, p. 120). Non-lawyers whose skill sets have access-enhancing potential might only be interested in collaborating with lawyers as venture capitalists, investors, or employers of lawyers. They might not be willing to work as employees of lawyers or independent contractors, given that these arrangements offer less control and less potential for profit to the non-lawyer (Hadfield, 2008).

While various forms of lawyer/non-lawyer collaboration are possible under the regulatory status quo, "fully integrated" multi-disciplinary practices are not (Dzienkowski and Peroni, 2000, p. 171). Full integration may not be necessary for large corporate clients to capture the benefits of collaboration, but Ray Worthy Campbell argues that the same cannot be said for individual consumers of legal services. Corporations are at liberty to create inter-professional collaborations among their own legal and non-legal employees. They can also create collaborations by having their in-house lawyers work with outside non-lawyers, or by having their non-lawyer executives work with outside lawyers. Individual clients do not have these options; if they are to benefit from collaboration it must come as an integrated package (Campbell, 2012, p. 33).

\subsection{Evaluation of the Insulation Critique}

Rolling back insulating regulation is not a complete panacea for North America's access to justice problems. The prevalence of small firms in the consumer legal services marketplace is not entirely a function of legal services regulation. This is demonstrated by the fact that insulating regulation has not prevented North American firms with corporate clientele from becoming much larger. One non-regulatory impediment to the emergence of nation-wide consumer law firms in the United States and Canada is the fact that the laws 
applicable to individuals' legal matters often vary significantly between the states and provinces of each country.

Nor should the extent of change in consumer legal services outside of North America be overstated. Despite the abolition of most insulating regulation, most consumer-clientele firms in the UK and Australia are still very small (Mark, 2010; Stephen 2013, Ch. 8). CoOperative Legal Services has encountered significant headwinds, including a loss of $£ 3.4 \mathrm{~m}$ in the first half of 2013, multiple changes of leadership, and a potential for "contagion" from troubles at the bank which is the firm's corporate sibling (Legal Futures 2013b; Solicitors Regulation Authority 2013). Only three Australian law firms have taken advantage of the opportunity to list on a stock exchange (Legal Futures, 2013; Sheehy, 2013). The actual value to consumers of the firm investments discussed above may also be questioned. For example, despite the emergence of technology-enabled legal services in the UK, surveys continue to find that clients are most satisfied with face-to-face advice (Legal Services Consumer Panel (UK), 2013).

Nevertheless, insulating regulation is subject to a very convincing access to justice critique. A strong theoretical case can be made that these strictures increase the cost of capital and therefore prices. They also seem to keep firms small when bigger firms might be more accessible, and prevent innovative collaborations between lawyers and others. It is difficult to predict the size and shape of the innovations which might emerge in a liberalized North American market, but it is very likely that they would make justice modestly more accessible. 


\section{Conclusion}

Is legal services regulation impeding the accessibility of justice in North America?

Justice would be more accessible if expert legal services were cheaper and more variegated, and if people had more awareness of their own legal needs. Regulatory reform can bring about these results, according to scholars such as Gillian Hadfield and Frank Stephen. Universal lawyer licensing and insulation of law firms are elements which distinguish North American legal services regulation from other common law regimes, and this article has asked whether these features are impeding the accessibility of justice.

The access to justice argument for regulatory liberalization is convincing. Multiple licensing and regulatory competition seem to promise mitigation of the anticompetitive effects of occupational licensing, without abandonment of its quality assurance. Opening law firms to non-lawyer investment and leadership should reduce capital costs and therefore prices, allow the emergence of larger and more accessible consumer law firms, and facilitate innovative collaborations between lawyers and non-lawyers. Co-Operative Legal Services and Slater \& Gordon, along with a handful of other innovative consumer law ventures, provide some indication of the success of this strategy in the UK and Australia. If access to justice is weaker in the United States and Canada than it is in other developed common law jurisdictions, regulation seems to be part of the explanation.

Of course, access to justice is not the only relevant consideration in a normative analysis of legal services regulation. We do not regulate lawyers in order to make justice more accessible; we regulate lawyers in order to protect vulnerable clients and third parties while promoting public goods such as the rule of law (Trebilcock et al., 1979; Barton, 2001; Woolley, 2012 ). If status quo North American lawyer regulation 
accomplishes these goals more effectively than the alternatives, then some sacrifice in the accessibility of justice might be acceptable. Moreover, North American lawyer regulators are dedicated to the "core values" of lawyer professionalism and the independence of the bar. Universal licensure and the insulation of lawyers from non-lawyers can be understood as necessary corollaries of these core values (Turriff, 2010; Semple, 2013).

Does regulating lawyers require a Hobbesian choice between the accessibility of justice on the one hand and quality assurance and core values on the other? Or, can North American legal services regulation be reformed in a manner which renders justice more accessible while safeguarding these more traditional goals? These questions are beyond the scope of this article. However, it is clear that the profession and its regulators must clearly understand, and mitigate to the greatest extent possible, the negative ramifications of lawyer regulation for the accessibility of justice. 


\section{Works Cited}

Law Society Act (Ontario).

Legal Services Act 2007 (UK).

Legal Services Consumer Panel (UK). (2013) Tracker Survey 2013 Briefing note 1: Usage and funding of legal services

<http://www.legalservicesconsumerpanel.org.uk/ourwork/CWI/documents/2013 Tracker Briefing 1_use_funding.pdf> (last accessed: 30 December 2013).

Abel, R. (2011) Just Law?, in: The paradox of professionalism : lawyers and the possibility of justice. S. L. Cummings, (Cambridge University Press).

Abel, R. L. (2009) State, Market, Philanthropy, and Self-Help as Legal Services Delivery Mechanisms, in: Private lawyers and the public interest : the evolving role of pro bono in the legal profession. R. Granfield and L. M. Mather, (Oxford University Press).

Agrast, M. D., Botero, J. C. and Ponce, A. (2011) World Justice Project Rule of Law Index 2011

<http://worldjusticeproject.org/sites/default/files/WJP_Rule_of_Law_Index_2011_ Report.pdf> (last accessed: 30 December 2013).

Albiston, C. R. and Sandefur, R. L. (2013) Expanding The Empirical Study Of Access To Justice, Wisconsin Law Review 2013: 101-120.

Baksi, C. (2011) Private equity buys into QualitySolicitors (The Law Society Gazette, October 21 2011) <http://www.lawgazette.co.uk/62702.article> (last accessed: 30 December 2013).

Barnett, H. M. (2012) A National Perspective on New York State Chief Judge Jonathan Lippman's Initiative, New York University Journal of Legislation \& Public Policy 15.

Barton, B. H. (2001) Why Do We Regulate Lawyers: An Economic Analysis of the Justifications for Entry and Conduct Regulation, Arizona State Law Journal 33.

Barton, B. H. (2011) The lawyer-judge bias in the American legal system: (Cambridge University Press).

Baxter, J., Trebilcock, M. and Yoon, A. (2012) The Ontario Civil Legal Needs Project: A Comparative Analysis of the 2009 Survey Data, in: Middle Income Access to Justice. M. Trebilcock, A. Duggan and L. Sossin, (University of Toronto Press).

Bindman, D. "Co-op calls on solicitors to 'stop the clock' on divorce work (Legal Futures: April 2, 2013)." from http://www.legalfutures.co.uk/latest-news/co-op-callssolicitors-stop-clock-divorce-work.

Bishop, W. (1989) Regulating the Market for Legal Services in England: Enforced Separation of Function and Restrictions on Forms of Enterprise, Modern Law Review 52: 326-351.

Boon, A. and Flood, J. (1999) Trials of Strength: The Reconfiguration of Litigation as a Contested Terrain, Law \& Soc'y Rev. 33.

Brockman, J. (2004) An Update on Self-Regulation in the Legal Profession (1989-2000): Funnel in and Funnel Out, Canadian Journal of Law and Society 19.

Brockman, J. (2010) Money for Nothing, Advice for Free: The Law Society of British Columbia's Enforcement Actions Against the Unauthorized Practice of Law, Windsor Review of Legal and Social Issues 29: 1-43. 
Buckley, M. (2010) Moving Forward on Legal Aid: Research on Needs and Innovative Approaches <http://www.cba.org/cba/Advocacy/PDF/CBA Legal Aid Renewal Paper.pdf> (last accessed: 30 December 2013).

Campbell, R. W. (2012) Rethinking Regulation And Innovation In The U.S. Legal Services Market, New York University Journal of Law \& Business 9: 1-70.

CBA A2J Committee. (2013) Reaching Equal Justice: An Invitation To Envision And Act <http://www.cba.org/cba/equaljustice/secure_pdf/Equal-Justice-Report-eng.pdf> (last accessed: 30 December 2013).

Choudhry, S., Trebilcock, M. and Wilson, J. (2012) Growing Legal Aid Ontario into the Middle Class: A Proposal for Public Legal Expenses Insurance, in: Middle Income Access to Justice. M. Trebilcock, A. Duggan and L. Sossin, (University of Toronto Press).

Clementi, D. (2004) Review of the Regulatory Framework for Legal Services in England And Wales: Final Report <http://www.jambar.org/clement_report.pdf> (last accessed: 30 December 2013).

Coy, P. G. and Hedeen, T. (2005) A Stage Model Of Social Movement Co-Optation: Community Mediation In The United States, The Sociological Quarterly 46(3): 405435.

Craig, J. (2006) Production values: Building shared autonomy, in: Production Values: Futures for Professionalism. J. Craig, (Demos).

Director General of Fair Trading (UK). (2001) Competition in professions $<$ http://www.oft.gov.uk/shared_oft/reports/professional_bodies/oft328.pdf> (last accessed: 30 December 2013).

Dzienkowski, J. S. and Peroni, R. J. (2000) Multidisciplinary Practice and the American Legal Profession: A Market Approach To Regulating The Delivery Of Legal Services In The Twenty-First Century, Fordham Law Review 69.

Fortney, S. S. (2005) The Billable Hours Derby: Empirical Data on the Problems and Pressure Points, Fordham Urban Law Journal 33: 171-192.

Friedman, M. and Kuznets, S. S. (1954) Income from independent professional practice: (National Bureau of Economic Research).

Garicano, L. and Hubbard, T. N. (2011) Specialization, Firms, and Markets: The Division of Labor within and between Law Firms, The Journal of Law, Economics, \& Organization.

Gillers, S. (1985) What We Talked about When We Talked about Ethics: A Critical View of the Model Rules, Ohio State Law Journal 46: 243.

Gilson, R. J. and Mnookin, R. H. (1985) Sharing among the Human Capitalists: An Economic Inquiry into the Corporate Law Firm and How Partners Split Profits, Stanford Law Review 37.

Goldberg, G. (2009) Practical Lawyering: The Skills You Did Not Learn in Law School: (Kaplan).

Gordon, R. W. (1988) The Independence of Lawyers, Boston University Law Review 68: 1.

Hadfield, G. K. (2000) The Price of Law: How the Market for Lawyers Distorts the Justice System, Mich. L. Rev. 98.

Hadfield, G. K. (2008) Legal Barriers to Innovation- The Growing Economic Cost of Professional Control Over Corporate Legal Markets, Stanford Law Review 60: 101146. 
Hadfield, G. K. (2010) Higher Demand, Lower Supply? A Comparative Assessment of the Legal Landscape for Ordinary Americans, Fordham Urban Law Journal 37: 129-156.

Hadfield, G. K. (2012) The Cost of Law: Promoting Access to Justice through the Corporate Practice of Law, International Review of Law and Economics.

Heinz, J. P., Nelson, R. L., Sandefur, R. L. and Laumann, E. O. (2005) Urban Lawyers: The New Social Structure Of The Bar: (University of Chicago Press).

Iacobucci, E. and Trebilcock, M. J. (2014) An Economic Analysis Of Alternative Business Structures For The Practice Of Law, Canadian Bar Review (forthcoming).

Katz, D. M. (2013) Quantitative Legal Prediction - or - How I Learned to Stop Worrying and Start Preparing for the Data Driven Future of the Legal Services Industry, Emory Law Journal 62.

Kerridge, R. and Davis, G. (1999) Reform of the Legal Profession: An Alternative Way Ahead, Modern Law Review 62.

Knake, R. N. (2012) Democratizing the Delivery of Legal Services, Ohio State Law Journal 73(1): 1.

Kobayashi, B. H. and Ribstein, L. E. (2011) Law's Information Revolution, Arizona Law Review 53.

Kritzer, H. M. (2010) Examining the Real Demand for Legal Services, Fordham Urban Law Journal 37.

Law Society of British Columbia. (2009) Code of Professional Conduct for British Columbia <http://www.lawsociety.ab.ca/files/regulations/Code.pdf> (last accessed: 30 December 2013).

Law Society of Upper Canada. (2000) Rules of Professional Conduct <http://www.lsuc.on.ca/WorkArea/linkit.aspx?LinkIdentifier=id\&ItemID=10272> (last accessed: 30 December 2013).

Legal Futures. (2013) Newly listed Australian law firm plans to follow Slater \& Gordon to UK (Legal Futures, 20 May 2013) <http://www.legalfutures.co.uk/latestnews/newly-listed-australian-law-firm-plans-follow-slater-gordon-uk> (last accessed: 30 December 2013).

Legal Futures. (2013b) Bank problems "will not affect" Co-operative Legal Services (8 November 2013) <http://www.legalfutures.co.uk/latest-news/bank-problems-willaffect-co-operative-legal-services> (last accessed: 30 December 2013).

Legal Services Board (England \& Wales). (2012) Annual Report and Accounts: 2011/2012 <http://www.official-documents.gov.uk/document/hc1213/hc01/0167/0167.pdf> (last accessed: 30 December 2013).

Legal Services Consumer Panel (UK). (2013) Tracker Survey 2013 Briefing note 3: Satisfaction with legal services <http://www.legalservicesconsumerpanel.org.uk/ourwork/CWI/documents/2013 Tracker Briefing 2_shopping.pdf> (last accessed: 30 December 2013).

Legal Services Corporation. (2009) Documenting the Justice Gap in America <http://www.lsc.gov/sites/default/files/LSC/pdfs/documenting_the_justice_gap_in _america_2009.pdf> (last accessed: 30 December 2013).

Lodder, A. R. and Zeleznikow, J. (2005) Developing an Online Dispute Resolution Environment: Dialogue Tools and Negotiation Support Systems in a Three Step Model, Harvard Negotiation Law Review 10. 
Love, M. C. (2002) The Revised ABA Model Rules of Professional Conduct: Summary of the Work of Ethics 2000, Georgetown Journal of Legal Ethics 15.

Luban, D. (1988) Lawyers and justice : an ethical study: (Princeton University Press).

MacFarlane, J. (2013) The National Self-Represented Litigants Project: Identifying and Meeting the Needs of Self-Represented Litigants <http://www.representingyourself.com/doc/report.pdf> (last accessed: 30 December 2013).

Mark, S. (2010) Before and After (Law Management Magazine, Issue 50, November 2010 at pp.30-31)

<http://www.bocsar.nsw.gov.au/lawlink/olsc/ll_olsc.nsf/vwFiles/Law_Mgt_Mag_ar ticle.pdf/\$file/Law_Mgt_Mag_article.pdf> (last accessed: 30 December 2013).

McShane, B. B., Watson, O. P., Baker, T. and Griffith, S. J. (2012) Predicting Securities Fraud Settlements and Amounts: A Hierarchical Bayesian Model of Federal Securities Class Action Lawsuits, J. of Empirical Legal Stud. 9.

Miller, G. P. (1996) Finance and the Firm, Journal of Institutional and Theoretical Economics 152(1): 89-107.

Moliterno, J. E. (2013) The American Legal Profession in Crisis: Resistance and Responses to Change: (Oxford).

Moorhead, R. (2010) Lawyer Specialization-Managing the Professional Paradox, Law \& Policy 32(2): 226.

Mortensen, R. (2013) Australia: The Twain (and Only the Twain) Meet- The Demise of the Legal Profession National Law, Legal Ethics 16.

Myrick, A., Nelson, R. L. and Nielsen, L. B. (2012) Race And Representation: Racial Disparities In Legal Representation For Employment Civil Rights Plaintiffs, New York University Journal of Legislation and Public Policy 15(3): 705-758.

OECD. (2007) Competitive Restrictions in Legal Professions <http://www.oecd.org/regreform/sectors/40080343.pdf> (last accessed: 30 December 2013).

Pagliero, M. (2010) Licensing Exam Difficulty and Entry Salaries in the US Market for Lawyers, British Journal of Industrial Relations 48(4): 726-739.

Parker, C. (1999) Just lawyers: regulation and access to justice: (Oxford University Press).

Paton, P. D. (2010) Multidisciplinary Practice Redux: Globalization, Core Values, And Reviving The Mdp Debate In America, Fordham Law Review 78: 2193.

Peppet, S. R. (2005) Lawyers' Bargaining Ethics, Contract, and Collaboration: The End of the Legal Profession and the Beginning of Professional Pluralism, Iowa L. Rev. 90: 475.

Pleasence, P. and Balmer, N. J. (2010) Horses for courses? People's characterisation of justiciable problems and the use of lawyers, in: The future of the legal services: Emerging thinking. L. S. B. (UK), (Legal Services Board).

Pratten, C. (2005) Economies of Scale, in: The Social Science Encyclopedia, 3rd ed. A. Kuper, (Routledge).

Rappaport, M. (2008). Competition bureau's study draws tepid reaction from legal community. Lawyers' Weekly.

Rhode, D. L. (1996) Professionalism In Perspective: Alternative Approaches To Nonlawyer Practice, N.Y.U. Rev. L. \& Soc. Change 22: 701.

Rigertas, L. A. (2012) Stratification Of The Legal Profession: A Debate In Need Of A Public Forum, Journal of the Professional Lawyer. 
Robins, J. "'If people want a Rottweiler, they can go somewhere else." (LegalVoice: October 4, 2012)." from http://legalvoice.org.uk/family/if-people-want-a-rottweiler-theycan-go-somewhere-else/.

Rose, N. "Co-op goes face-to-face with nationwide family legal aid service (Legal Futures: April 23, 2013)." from http://www.legalfutures.co.uk/latest-news/co-op-goes-faceto-face-nationwide-family-legal-aid-service.

Samuelson, S. S. and Jaffe, L. G. (1990) Statistical Analysis of Law Firm Profitability, B.U. L. Rev. 70.

Sandefur, R. L. (2012) Money Isn't Everything: Understanding Moderate Income Households' Use of Lawyers' Services, in: Middle Income Access to Justice. M. Trebilcock, A. Duggan and L. Sossin, (University of Toronto Press).

Semple, N. (2013) Core Values: Professionalism and Independence Theories in Lawyer Regulation <http://ssrn.com/abstract=2262518> (last accessed: 30 December 2013).

Shaked, A. and Sutton, J. (1981) The Self-Regulating Profession, Review of Economic Studies 47 217-234.

Sheehy, B. (2013) From law firm to stock exchange listed law practice: an examination of institutional and regulatory reform, International Journal of the Legal Profession 20(1): 3.

Slater \& Gordon. "Fixed Fees ${ }^{\mathrm{TM}}$ in Family Law." from http://www.slatergordon.com.au/areas-of-practice/victoria/general-legalservices/family-law/fixed-fees.

Slater \& Gordon. (2012) Annual Report: 2011/2012 $<$ http://www.slatergordon.com.au/files/editor_upload/File/annual-report201112.pdf> (last accessed: 30 December 2013).

Solicitors Regulatory Authority (England and Wales). (2013) Catching a chill: law firms and risks of group contagion <http://www.sra.org.uk/documents/solicitors/freedomin-practice/risk-contagion-law-firms.pdf> (last accessed: 30 December 2013).

Stephen, F. (2013) Lawyers, Markets and Regulation: (Edward Elgar).

Stephen, F. and Melville, A. (2008) The Economic Organisation of the Faculty of Advocates <https://http://www.escholar.manchester.ac.uk/api/datastream?publicationPid=u k-ac-man-scw:5b274\&datastreamId=FULL-TEXT.PDF> (last accessed: 30 December 2013).

Stobart Barristers. "Driving Offences: What is your Licence Worth?", from http://www.stobartbarristers.co.uk/personal/driving-offences/.

Susskind, R. E. (2008) The end of lawyers? : rethinking the nature of legal services: (Oxford University Press).

Teece, D. J. (1980) Economies of scope and the scope of the enterprise, Journal of Economic Behavior and Organization 1(3): 223-247

Todd, R. "The Going Rate. (First published in Canadian Lawyer Magazine, Vol. 35, No. 32, June 2012)." from http://www.canadianlawyermag.com/images/stories/pdfs/Surveys/2012/legalfee ssurvey2012.pdf.

Trebilcock, M. (2008) Report of the Legal Aid Review $<$ http://www.attorneygeneral.jus.gov.on.ca/english/about/pubs/trebilcock/legal_a id_report_2008_EN.pdf> (last accessed: 30 December 2013). 
Trebilcock, M. J., Tuohy, C. J. and Wolfson, A. D. (1979) Professional regulation : a staff study of accountancy, architecture, engineering and law in Ontario prepared for the Professional Organization Committee: (Ministry of the Attorney General).

Turriff, G. (2010) The Consumption of Lawyer Independence, International Journal of the Legal Profession 17: 283.

Van Hoy, J. (1997) Franchise Law Firms and the Transformation of Personal Legal Services: (Quorum Books.).

Webb, J. (2008) The Dynamics of Professionalism: The Moral Economy of English Legal Practice - and Some Lessons for New Zealand, Waikato L. Rev. 16.

Wilkins, D. B. (1993) Making Context Count: Regulating Lawyers after Kaye, Scholer, Southern California Law Review 66: 1145.

Winston, C., Crandall, R. W. and Maheshri, V. (2011) First Thing We Do, Let's Deregulate All the Lawyers: (Brookings Institution Press).

Woolley, A. (2004) Time for Change: Unethical Hourly Billing in the Canadian Profession and What Should be Done About It, Can. Bar Rev. 83.

Woolley, A. (2012) Why do we Regulate Lawyers?, in: Why Good Lawyers Matter. D. L. Blaikie, T. Cromwell and D. Pink, (Irwin Law Inc. ).

${ }^{1}$ E.g. Washington State's legal technician program, Ontario's licensed paralegals, and British Columbia's notaries. In Canada immigration consultants and a few others who practice before federal administrative tribunals may offer legal services within a narrow context. Each of these exceptions only allows a small group of people to provide a small and narrowly defined range of legal services.

2 E.g. Weitz \& Luxenberg, which describes itself as the largest personal injury firm in New York State, employs only 50 lawyers. (http://www.weitzlux.com/personal-injury-lawfirm_1141.html 